\title{
A review of Turkey's high-speed rail experience
}

\author{
U. Sanili Aydin, ${ }^{1, *}$ A.N. Uste ${ }^{2}$ \\ ${ }^{1}$ Manisa Celal Bayar University, Department of Political Science and \\ International Relations, Manisa, 45140, Turkey \\ ${ }^{2}$ Dokuz Eylul University, Department of Public Administration, \\ Izmir, 35390, Turkey \\ *e-mail: ulaydin91@hotmail.com
}

Submitted: 22/03/2021; Accepted: 25/04/2021; Published online: 07/05/2021

Abstract: The multidimensional characteristics of the HSR networks make debated the benefits of them. In this context, the aim of this study is to review of Turkey's HSR systems from spatial equity perspective within the framework of recent research and developments. The latest secondary data from the official statistics of the Ministries of Development; Environment and Urbanization; Industry and Technology of Turkey has been used for the purpose of the analysis. The research methods included: critical analysis of the source literature, analysis of secondary data (desk-research) and graphic methods (tables and maps), by means of which the results of the study have been presented. The main argument of study is that considering the current geographical location of the HSR network of the country, it creates challenges in terms of spatial equity and deepens the regional polarization. The existing HSR network has facilitated mobility, especially in terms of domestic tourism. However, the usage of the HSR by a limited part of population and restrictions applied due to the COVID-19 pandemic question the amount of returns of the HSR's costs, which are enough expensive investments in Turkey. On the other hand, increasing inequalities arising from the HSR infrastructures shaped on the basis of factors such as the geographical features of the country, general development level, population and demand density, are tried to be minimized by roadway and airway alternatives.

Keywords: COVID-19; economic development; high-speed rail; spatial equity; Turkey 


\section{Introduction}

Technological innovations and globalization have increased the share of service sectors in countries' economies as well as their importance and efficiency. Although the process of globalization includes the relatively free movement of goods, services and capital, but not of labour [1], all these activities boost the free movement of people as much as possible. On the other hand, it would not be true to consider the increased human mobility only at the global level. As a part of the countries' development agenda, transportation projects facilitate the domestic mobility of people. The progress in transportation sector has been supported by the variety of access options making easier to travel more at the local and regional levels.

Railway is one of the first and most important elements of public transport, which is increasingly significant as a part of the transportation systems. The basic economic industries such as coal, iron and steel have been integrated among themselves by the railway. In this sense, the railway contributes to the formation of market relations at national and international scale by providing spatial integration. It is the engine of integration and economic development, making a great contribution to the economic, social and cultural development along the routes. However, except for developed economies, railway projects are enough expensive investments requiring costly maintenance afterwards. Therefore, they must be carefully planned [2].

As known an environmentally friendly mode in contemporary world in the light of the searches for alternative energy sources, railway allows to transport more passengers simultaneously at an affordable cost via wagons. In this sense the HSR networks are considered as the alternative projects to congested road traffics in 1960's. While countries like Japan, France are the pioneers of these projects, the HSR networks exist in several parts of the world today.

In its Council Directive 96/48/EC of 23 July 1996 on the interoperability of the trans-European high-speed rail system the Council of the European Union (EU) has defined the HSR as an infrastructure and rolling stock enabling at least $250 \mathrm{~km} / \mathrm{h}$ on specially built lines and $200 \mathrm{~km} / \mathrm{h}$ on upgraded high-speed lines [3]. HSR is still a grounded, guided and low grip transport system: it could be considered to be a railway subsystem [4]. However, the speed is the main factor distinguishing it from conventional railway networks. An easy access achieved by HSR has provided new opportunities for cities located on the route of the HSR lines and has often revitalized the significance of railway stations [5].

Since 2000s, Turkey has needed to revise its transportation policies in the light of global, international and regional developments. The start of membership negotiations in 2004 with the EU - the world's largest trading bloc - has been one of the most important driving forces in this process. Emerging new markets nearby in 
the post-Soviet areas and the softened relations of the West with Iran have created the need for more advanced transport networks in Turkey. Initiatives made in the field of freight transportation have also been reflected in domestic passenger transportation of Turkey. Traditionally, the country has a satisfying road network. A significant impetus has been achieved especially in domestic airline passenger transportation by widening local airport networks. By opening the intercontinental Marmaray and Baku-Tbilisi-Kars railway lines, a direct connection has been established with Georgia and Azerbaijan, and an important corridor has been established in the connection of the country to Asian and European transportation networks through the Black Sea region. Both lines are purposed for freight and passenger transportation. On the other hand, the most important development in the railway sector during this period is Turkey's investments in the HSR.

In the light of above mentioned, this paper aims to review the way that the country has reached in the HSR systems after 2000 as a part of Turkey's transportation policies from a spatial equity perspective, focusing on recent research and developments. The paper is conducted in six sections. Following the introduction part, the materials and methods used in this study have been explained in the second section. The literature has been reviewed in the third part of the paper. It has been aimed to draw a general framework of Turkey's railway transportation policies in globalization era in the fourth section. The same section involves an analysis of Turkey's experience on the HSR, reviewing policy documents, instruments for implementation, legal regulation documents, national development plans and similar documentations as well as surveys conducted previously. The research is supported by the official statistics. The findings of the study are included in the fifth section. The paper is concluded with final part.

\section{Materials and methods}

The article focuses on Turkey's HSR networks, which is a relatively new experience for this country in comparison with other modes of transport. The analyses included herein should be seen as a case study. The submitted findings are results of evaluations taking into the consideration the determinants of the HSR systems from spatial equity perspective. Research is conducted by Manisa Celal Bayar University in Manisa and Dokuz Eylul University in Izmir, Turkey.

The data were collected using various methods, including a review of the literature, public documents and statistics, interviews and official declarations of the HSR network authorities and results of surveys conducted by professional and public organizations on the usage, benefits and performance of the HSR network in Turkey.

The data obtained allowed to analyse the geographical orientation of the HSR network policies and numbers of the HSR users and their aim to prefer the HSR. The 
aim of the study was to provide a description of the HSR networks in Turkey in terms of equal benefit and inclusiveness.

The following hypotheses were formulated in the study preparation phase:

- Turkey's investments in the HSR systems are the results of multivectoral transport policies within the adaptation processes to the globalizing world.

- The development of the HSR network in the western region, which is more developed compared to the eastern region of the country, will increase the spatial inequality.

The research limitations included the availability of the detailed data about the socio-economic profiles of the HSR users.

\section{Literature review}

Investments made in the transport sector are generally carried out by the public sector, as they are included in public infrastructure expenditures and have a high multiplier effect [6]. Public spending on infrastructure is one of the contentious subjects of domestic policies due to the debates on its productivity and benefits. Aschauer's [7] argument about the significant benefits of transport infrastructure investment both for the economy and society has been responded counter-reactions in the literature. The disagreement arises regarding the multi-characteristic nature of transport infrastructure investment and appraisal methodologies of it in this sense [8].

But in spite of all disputes, as a model of development supported by several international and regional financial organizations, infrastructures have founded a basis of an industrial and information revolution in the transmission of goods, people, power, information and Internet over increasingly vast distances [9]. The distribution of a huge number of benefits providing by infrastructures has been far from equal that has been started to question by citizens [9].

Wider economic impacts of transport are enough well known issue, requiring benefit analysis of purposed infrastructure projects. Countries follow different paths in project assessments from macroeconomic, micro and meso economic effects such as agglomeration or competition benefits. The UK Department for Transport has preferred to develop the quantification method for the HSR project linking London to Birmingham, then Manchester and Leeds, which was the first major transport infrastructure project including wider economic impacts. However, countries like Chile or South Africa focuses on social mix and desegregation benefits of transport projects [10]. 
The growth-pole theory stresses the agglomeration benefits associating with the spatial concentration of population and activities, as well as the presence, quality and extent of the infrastructural systems [11]. Although long-distance transportation infrastructures connect territories, increase the possibilities of interconnections and exchanges [12], push economic development, they can also create the inequalities between regions.

Monzon et al. [13] has described equity as a distribution of a given effect, frequently associated with terms of "justice", “fairness" or "cohesion" in transport literature $[14,15,16]$. The level of equity analysis - international, national, regional or local - has direct effect on the results caused by the HSR and cities far from the HSR stations face with a risk of reallocation of economic activities as companies may prefer to move to regions closer to the transportation networks $[15,13)$. Such preferences can increase easily the gap between regions and push polarization [13].

According to investigations of Church et al. [17], most of the studies on relationship between transportation and its impacts has mainly focused on two approaches: "category approach" and "spatial approach". The first approach aims to examine the travel patterns, attitudes and needs of disadvantaged social groups concerned with the transport systems, like women, citizens without paid employment or older. However, the second approach is interested in spatial equity and problems caused by poor public transport access [17].

Thus, there are discussions in the literature regarding the contradiction between spatial equality and the transportation system. A spatial equity can be considered as a geographical location of an individual, group or region influenced by a transport infrastructure project [18].

Biggiero et al. [19] has defined the spatial equity or spatial accessibility "as a measure of the ease of travelling from an origin to a given destination via a given mode or set of transport modes", emphasizing the cruciality of achievement of equity in the allocation of public resources. Although current investments in the HSR systems have made an easy access, but also have created equity issues. The benefits of new HSR lines are undeniable in terms of improvements in accessibility opportunities. Such infrastructure constructions can increase the attractiveness of the regions, fostering their locational values. However, the HSR systems networks can also create a spatial imbalance, increase development gaps between regions [19]. Polarizing the levels of development between territories, the region out of the routes of the HSR systems networks may stay in shadow of that one which is on the route of them. Considering the citizens' equal rights of access to all services provided by the public authorities, the criticism about the HSR systems' encouragement of inequality has a rational justification. Suggesting the new method - SUstainable 
Mobility INequality Indicator (SUMINI) to appraise the transportation infrastructures as an alternative to Multi-Criteria Analysis (MCA) and Cost Benefit Analysis (CBA), Thomopoulos and Grant-Muller [8] have emphasized the role of new technological advances in more inclusive assessment of the wider impacts of them. Based upon a composite indicator and MCA, it is argued that as an easily accepted and complementary approach SUMINI is not in competition with traditional CBA. It could methodologically provide a new and important answer to the traditionally hard question of how to appraise equity and other wider impacts, such as accessibility, land use and socio-economic and environmental effects [8].

Defining spatial equity as an ambiguity, Buhangin [20] has evaluated it in both physical and socio-economic senses. While it can be the equitable development of land use from physical perspective, in the socio-economic terms it can be considered as an equitable flow of goods and services from one spatial arena to another. Buhangin [20] has accepted a spatial equity as a parameter for sustainable development especially in indigenous regions in both senses.

HSR is a type of transport by which the movement of people is mainly aimed as an integrated part of economic development goals, focusing on connectivity and cooperation between regions. As all types of transportation contain an interaction element in essence, the HSR projects have cultural and social aspects also. In this context, it can be considered that the HSR has the multidimensional characteristics. HSR policy, faces at the end a set of dilemmas that must be dealt with politically also [21]. Because the HSR system is an infrastructure construction and service operation with high cost that makes it a focus point of hot debates [22] alongside of spatial equity issues.

In the case study for Spain, Monzon et al. [13] has investigated the accessibility impacts of the HSR network construction on spatial equity. Determining a more polarised pattern in Spain, it has been found that a speed acceleration from $220 \mathrm{~km} / \mathrm{h}$ to $300 \mathrm{~km} / \mathrm{h}$ in a given route results in heavy negative effects on spatial equity between locations with and without the HSR service [13]. Several significant factors have been highlighted in the study that must be taken into consideration in the planning process. In order to achieve the maximum positive spatial equity results, following factors require to be considered at the planning period: "the level of accessibility of the city in the initial situation as regards the quality of its railway infrastructures; its geographical position in terms of proximity to major population centres; the existence of a HSR station; and the quality of the transport network from the cities to the nearest HSR station” [13].

The qualitative analysis of the equity impacts of the HSR network conducted by Biggiero et al. [19] has showed that in Italy the problem of economic/geographic exclusion perceived by travellers does exist. 
In the case study of Yangtze River Delta (China), Wang and Duan [22] have argued that the HSR development may cause the new dimension in transport inequity and besides of the accessibility the affordability should be taken into consideration in future equity studies on the HSR development in China.

The spatial equity approach considers to act from a more strategic view, involving both the possible benefits and their spatial distribution. It's required an evolution of the consequences not only on the cities in the HSR corridors with a station, but also on other ones outside the route, regardless of whether or not they have a station [13].

\section{Turkey's experience on high-speed rail}

Following the Industrial Revolution in the Western Europe, railways have been constructed by using foreign capital as a result of the raw material supply of the colonial countries and their search for new markets for finished goods in the Ottoman Empire. With the declaration of the Republic, the railways have built and operated by the state, considering the economic and social benefits of the country. In this period, the construction of highways has been designed to connect railways and ports to the inner regions of the country. Another remarkable feature of this period is the construction of coherent lines. By providing loops, the coherent lines have shortened the distances, reducing the transportation costs [23].

However, after the 1950s, the importance given to the railway has decreased with the rapid development of highways, which had pushed the railway construction and transportation to the background (Table 1).

Table 1. Share of transport sector investments in total investments in development plans [24]

\begin{tabular}{|l|c|l|l|}
\hline $\begin{array}{l}\text { Five-year } \\
\text { development } \\
\text { plan by } \\
\text { years }\end{array}$ & $\begin{array}{l}\text { Percentage of } \\
\text { Transportation } \\
\text { Sector in General } \\
\text { Investments }\end{array}$ & $\begin{array}{l}\text { Percentage of the } \\
\text { Highway System in } \\
\text { the Transportation } \\
\text { Sector }\end{array}$ & $\begin{array}{l}\text { Percentage of the } \\
\text { Railway System in } \\
\text { the Transportation } \\
\text { Sector }\end{array}$ \\
\hline $1963-1967$ & 13.7 & 71.3 & 17.5 \\
\hline $1968-1972$ & 16.1 & 72.1 & 18.8 \\
\hline $1973-1977$ & 14.5 & 52.1 & 13.9 \\
\hline $1979-1983$ & 16.3 & 60.7 & 10.6 \\
\hline $1985-1989$ & 25.4 & 49.4 & 16.0 \\
\hline $1990-1994$ & 26.5 & 62.6 & 7.2 \\
\hline $1996-2000$ & 22.7 & 63.6 & 6.5 \\
\hline
\end{tabular}


Since 2003, the allocation for railway investments has increased and the development of railways has been seen as one of the targets for transportation sector [23]. In 2009 Turkey has gained its first experience on the HSR with AnkaraEskisehir line. In 2011, Ankara-Konya, in 2013 Eskishehir-Konya, in 2014 AnkaraEskisehir-Istanbul and Konya-Istanbul train services have started, making possible the one-day travels between these regions. The total length of the completed HSR lines is $1,213 \mathrm{~km}$.

Increasing importance of multi-modal transportation systems in globalization era in the context of environmental and climate change issues and membership negotiations with the EU have been the most significant motivators of this process. As one of the membership precondition within the negotiation chapters, the EU has proposed the restructuring of the railway sector of Turkey. In order to redefine the role of railway in the transportation sector, to produce efficient and compatible commercial-oriented services with the market conditions, TCDD Tasimacilik SJC has been established as subsidiary of TCDD Turkish Railways by the "Law on the Liberalisation of Railway Transportation in Turkey” in 2016.

In the light of these developments urban rail transportation systems have also provided significant advantages in parallel to increase of population in the cities of Turkey (Fig. 1).

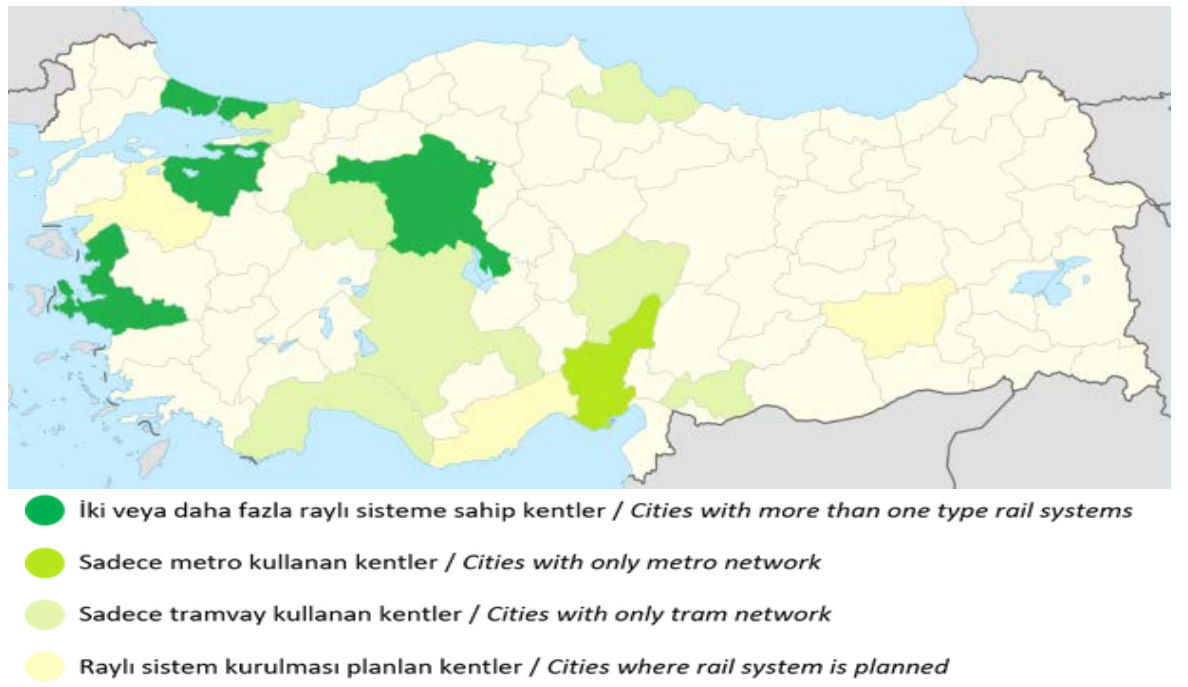

Figure 1. Map of urban rail systems in Turkey (2021) [25] 
Metro, light rail system, tram, funicular and suburban system is used In twelve cities of Turkey. In spite of the restrictions during pandemic, the number of passengers reached 1.46 billion in 2020 with some improvements such as the newly opened lines, night services, and an integration of bus lines to the rail system. The total urban rail line length is $782 \mathrm{~km}$ [25].

In 2020 the length of the railway network (including both the conventional and high speed lines) summed up to 12,803 km in length (Table 2). While the share of the railway investments was 33 percent in 2013 in total investment for transportation and communication, this rate was increased to 47 percent in 2020. 29 billion US dollars has been invested in the railway sector between 2013-2020. It is estimated that railway network will be extended to 25,000 km in length by 2023 [26].

Table 2. Railway network by year $(\mathrm{km})$ [26]

\begin{tabular}{|c|c|c|c|c|c|c|c|}
\hline Years & 2002 & 2005 & 2010 & 2015 & 2016 & 2017 & 2020 \\
\hline Length & 10925 & 10973 & 11940 & 12532 & 12532 & 12608 & 12803 \\
\hline
\end{tabular}

It has been planned to connect fifteen largest provinces of the country by the HSR. Primarily Ankara-Eskishehir, Ankara-Konya, Konya-Istanbul and Ankara-Istanbul HSR have been started to operate (Fig. 2) and Turkey has become the sixth country in Europe, eighth in the world in the HSR operation.

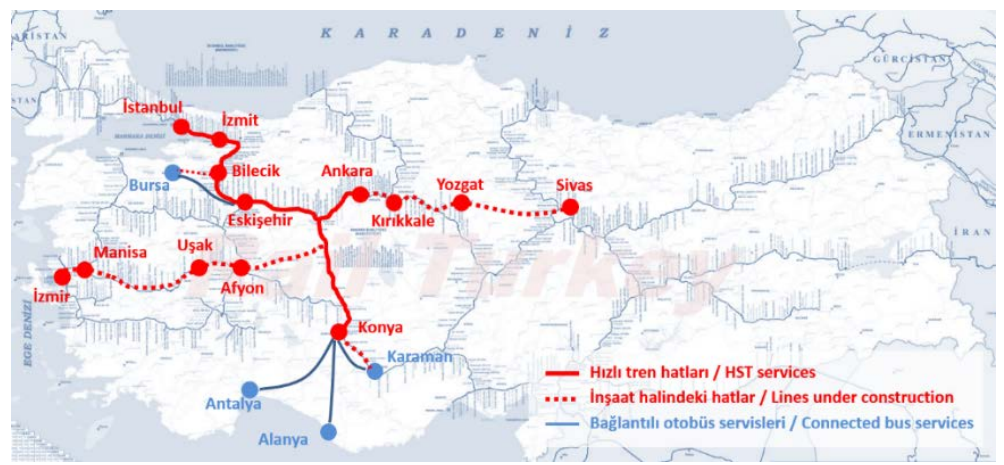

Figure 2. Map of Turkey's HSR network (2019)[29]

There are daily 44 train services in the winter season and 52 train services in the summer season. 53.2 million people have used the HSR as a travel mean between 2009-2019 in total [27]. 29.4 percent of the HSR users prefers it for business purposes and 12.7 percent of passengers uses the HSR to go to and from school. While women mostly use the HSR for visiting family members and friends (40.7 percent), men mostly use the HSR for business purposes (37 percent) [27]. 
Regulation on the rights of passengers traveling by rail has been published in 2019, involving the procedures and principles regarding the rights and obligations of passengers traveling by rail [28].

There is no connection between the HSR and conventional railway lines in Turkey. The HSR network is developing directly with the construction of the HSR infrastructure. However, there are studies in different regions of the country (south and north) for the utilization of various line connections as the HSR network by improving the conventional railway lines. There is no any HSR line implementation in Turkey by which both freight and passenger transportation is carried out together or as double line [30].

As it is shown in the map (Fig. 2), the current HSR network and the HSR lines have been planned to be completed in the near future is Ankara centered and connect the largest four cities of the country.

On the other hand, Ministry of Industry and Technology of Republic of Turkey General Directorate of Development Agencies has published a socio-economic development ranking research of provinces and regions - SEGE 2017 [31]. Totally fifty-two variables based on demography, employment, education, health, competitive and innovative capacity, finance, accessibility and life quality have been used in the conducting of research. According to the obtained index values, six levels of development of provinces have been determined in Turkey. The development levels that emerged as a result of the research are mapped (Fig. 3).

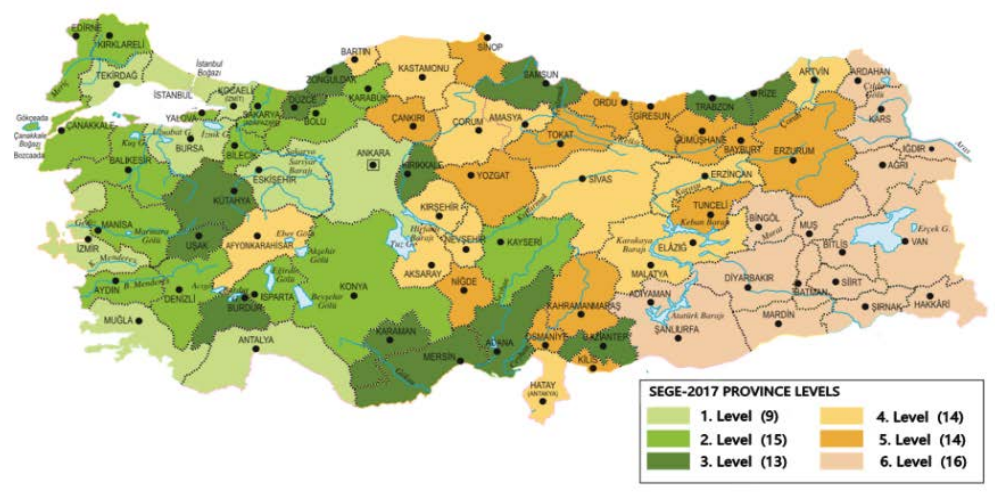

Figure 3. The map of development level of provinces of Turkey [31] 
It must be noted that there are eighty-one provinces in total according to the administrative territorial division of Turkey. There are nine provinces in the first development level group, fifteen provinces in the second group, thirteen provinces in the third group, fourteen provinces in the fourth group, fourteen provinces in the fifth group and sixteen provinces in the sixth group [31].

SEGE - 2017 research provides a better understanding of spatial inequality, which is one of the basic hypotheses of our study, supporting it with visuals.

\section{Findings}

Comparing two maps (Figs. 2 and 3), it has been found that the first seven most developed provinces of the country are among the provinces that already have or will have the HSR connection in the near future. Four of the remained provinces with existing or potential HSR connection are among the provinces of the second development level group.

As it is illustrated in the map (Fig. 3), there is a great difference between country's western and eastern parts. The geographical characteristics distinguish these two regions. The eastern part of the country consists of more rugged terrain with high mountains (Fig. 4), which increases the cost of infrastructure and technically limits the ability to speed up and decelerate of the HSR systems. However, the western regions are relatively flat (Fig. 4).

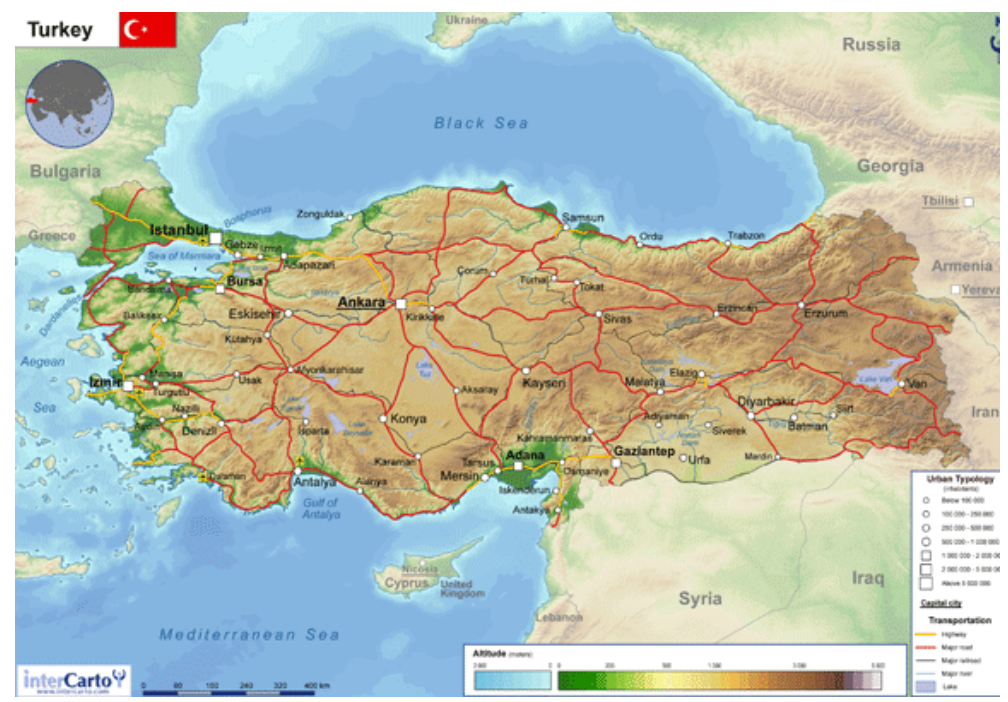

Figure 4. Physical map of Turkey [32] 
Secondly, the western regions of the country are located on the coastlines or close to them. However, eastern regions are lack of such opportunity. Turkey's geographical diversities are one of the primary factors shaping the socio-economic structural features between its regions.

The fact that the western and coastal parts of the country are more developed is the main starting point of a movement from the eastern regions to here.

Reducing the regional disparities and accelerating economic development has been determined as a priority in some HSR projects. Decreasing the traffic density has been determined as a secondary goal in such projects, aiming to transfer the economic and social dynamism of the developed regions to the developing regions with the HSR networks [33]. In terms of clear regional differences, inefficient resource allocation, current HSR infrastructures increase spatial inequalities rather than removing them. Considering that the HSR lines develop the intercity accessibility of peripheral cities along the HSR network based on the highway network and reduces the spatial inequalities, it must be focused on the peripheral areas in regional planning in order to maximize the benefits with limited investment [34]. Increasing the network density around cities with inferior accessibility and promoting multi-modes for accessing to HSR is also an effective way to improve regional development [34].

In order to achive the above mentioned concequences, the HSR networks must also cover underdeveloped regions. But considering the geographical conditions, population density, economic activities, or demand volume, such investments can be expensive and not rational.

On the other hand, the Turkish government has launched its transportation policies in parallel with country's tourism and trade policies after the 2000s. It has been succeeded to reduce the spatial inequalities between eastern and western regions as a result of opening new airports and increasing number of domestic flights. There are fifty-three airports (Fig. 5) in Turkey [35]. 


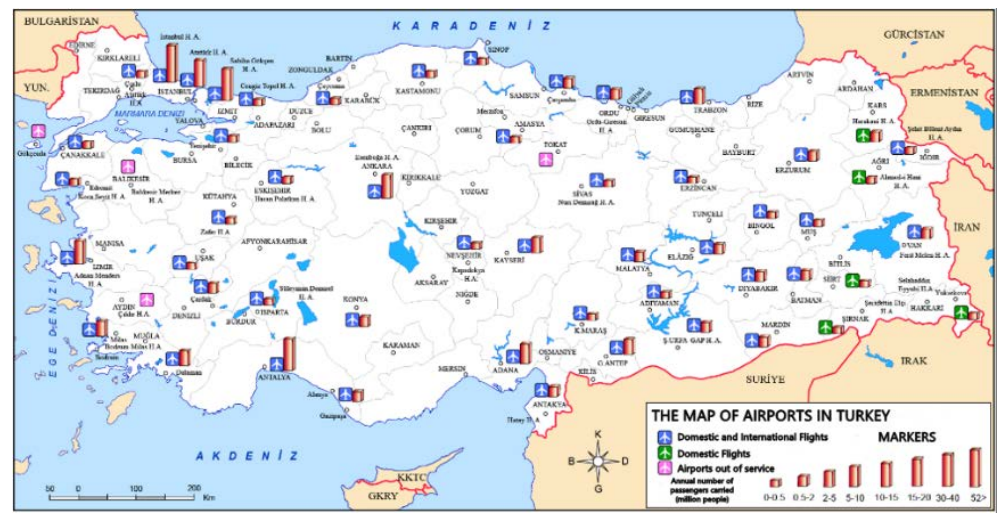

Figure 5. The map of airports in Turkey [35]

These developments have also revitalized existing airports located on the HSR network routes. In terms of temporal competition, scheduling strategies are important to improve network efficiency and optimize time slots for both air and the HSR travel [36] during planning and policy-making to achieve sustainable operations and the development of the passenger rail system [37].

The surveys conducted on the HSR systems operating in Turkey since 2009 have found that the existing network contributes mostly to domestic tourism sector. Considering the crucial role of transport for the increase of tourist flow [38], this has been an expected effect. Additionally, examining the profile of the passengers, findings have showed that the HSR lines are mostly used by students and preferred by those people who want to save time [39].

On the other hand, COVID-19 pandemic deeply affects each sector of economy as well as transportation sector. In this sense, the strict measures have been implemented against virus. Since pandemic has been declared, Turkey imposes curfew in several periods. Restriction on public transport, closing of touristic places decrease the usage of the HSR services in the country. Considering that the HSR infrastructures are the expensive infrastructures and have started to operate more recently in Turkey, this is a serious disadvantage in terms of cost recovery.

\section{Conclusion}

The HSR networks can be described as a product of technological solutions developed in the field of railways in order to meet the increasing demand for geographical mobility of the capital and labour. In fact, the experiences confirm that the regions which are accessible by the HSR systems, become more attractive for 
capital to invest, while the regions where the HSR does not reach, are spatially polarized. Therefore, unequal investment in the HSR systems causes an increase in unequal development between regions.

More than 420,000 passengers are carrying by the HSR on a typical weekday in Japan. An extensive HSR networks include several cross-border international links between several European countries. The HSR projects have been rapidly developed in China in last 15 years, supported by huge governmental funding. While expensiveness of the HSR systems has been questioned in developing countries, whereas it is costly for workers to pay for faster travel, they are favoured due to the energy savings, transportation benefits and environmental considerations.

Turkey has achieved an important step in the transport sector after the 2000s. Due to its geographical position and the role of bridge between continents, Turkey is a significant part of several regional and international transportation projects in the globalization age.

The geographical conditions of the country also play a deterministic role in shaping the domestic transportation policies. The main goal of the domestic part of transport policy has been focused on the elimination of the development disparities between the western and eastern regions of the country in these years.

In this context, Turkey has started to operate the HSR in 2009. The existing HSR network is generally located in the western parts of the country, which are geographically more suitable for such infrastructures and where a large number of the population lives. This situation has deepening the spatial inequalities between the developed western and underdeveloped eastern part of Turkey. These inequalities arising from transport opportunities have been tried to be removed by the airline mode.

On the other hand, the share of rail passenger transport has fallen to 1.3 percent in 2018, which has been accounted 42 percent in the 1950s, mainly due to the new opened highways and airports in both parts of the country. In addition to infrastructure investments, it is inevitable for the country to realize reforms involving participation of private companies and liberalization in passenger transportation in order to increase the share of the passenger transportation by the HSR.

The HSR systems are known as environmental and economical transport mode, but expensive investments. The restrictions, lockdowns and a need to protect social distance due to the COVID-19 have added a new dimension to both urban and public transport policies [40]. Therefore, the HSR infrastructure investments in Turkey must be addressed so as to ensure the financial efficiency and spatial equity, 
considering the factors such as increasing natural disasters, health threats, climate change and environmental issues in recent years.

\section{References}

[1] S.J. Burki, Rising Powers and Global Governance, 1st Edition, Palgrave Macmillan, New York, 2017.

[2] B. Eller, Sz. Fischer, Tutorial on the emergence of local substructure failures in the railway track structure and their renewal with existing and new methodologies. Acta Technica Jaurinensis 14 (1) (2021) pp. 80-103. doi: https ://doi.org/10.14513/actatechjaur . 00565

[3] The Council Directive 96/48/EC. Official Journal L 235 17/09/1996 pp. 6 24. [cited 2021-04-24].

URL https://eur-lex.europa.eu/legalcontent/EN/TXT/?uri=CELEXpercent 3A31996LO०4

[4] UIC. The Definition of High Speed Rail. "UIC eNews" Nr 596 dated 26 April 2018 [cited 2021-04-24].

URL https://WWw. uic.org/com/enews/nr/596-highspeed/article/the-definition-of-high-speedrail?page=thickbox_enews

[5] M. Garmendia, C. Ribalaygua, J.M. Urena, High speed rail: Implication for cities. Cities 29 (2012) pp. 526-531.

doi: https://doi.org/10.1016/j.cities.2012.06.005

[6] M. Demir, E. Sever, The effect of public infrastructure expenditures on economic growth: the case of Turkey (1980-2007) (Kamu altyapi harcamalarinin ekonomik buyume uzerindeki etkisi: Turkiye uzerine bir inceleme (1980-2007)). Marmara Universitesi I.I.B.F. Dergisi XXV (2) (2008) pp. 99-118 (in Turkish).

[7] D.A. Aschauer, Is public expenditure productive? Journal of Monetary Economics 23 (2) (1989) pp. 177-200.

doi: https ://doi .org/10.1016/0304-3932(89)90047-๑

[8] N. Thomopoulos, S. Grant-Muller, Incorporating equity as part of the wider impacts in transport infrastructure assessment: An application of the SUMINI 
approach. Transportation 40 (2013) pp. 315-345.

doi: https ://doi .org/10.1007/s11116-012-9418-5

[9] D. Durrant, Infrastructure, equity and urban planning: A just process for the allocation of benefits and burdens, In: J. Bishop (Ed.), Building sustainable cities of the future. green energy and technology, 1st Edition, Springer, Cham, 2017, pp. 141-162.

doi: https ://doi.org/10.1007/978-3-319-54458-8_8

[10] C. Cheze, R. Negre, Wider economic impacts of high-speed rail: Example of agglomeration benefits assessment on Bretagne Pays de Loire high speed rail project, Transportation Research Procedia 25 (2017) pp. 5307-5324.

[11] M.D. Thomas, Growth pole theory, technological change, and regional economic growth, Papers In Regional Science 34 (1) (1975) pp. 2-25. doi: https://doi .org/10.1007/BFO1941308

[12] G. Mazzeo, Impact of high speed trains on the hierarchy of European cities, Jahrbuch für Regionalwissenschaft 32 (2012) pp. 159-173.

doi: https://doi.org/10.1007percent 2Fs10037-012-0066-1

[13] A. Monzon, E. Ortega, E. Lopez, Efficiency and spatial equity impacts of high-speed rail extensions in urban areas, Cities 30 (2013) pp. 18-30. doi: https://doi.org/10.1016/j.cities.2011.11.002

[14] J. Bröcker, A. Korzhenevych, C. Schürmann, Assessing spatial equity and efficiency impacts of transport infrastructure projects, Transportation Research Part B (44) 2010 pp. 795-811.

doi: https://doi.org/10.1016/j.trb.2009.12.008

[15] E. Lopez, J. Gutierrez, G. Gomez, Measuring regional cohesion effects of large-scale transport infrastructure investments: An accessibility approach, European Planning Studies 16 (2) 2008 pp. 277-301.

doi: https ://doi.org/10.1080/09654310701814629

[16] D. Peters, Cohesion, policentricity, missing links and bottlenecks: Conflicting spatial storylines for Pan-European transport investments, European Planning Studies 11 (3) (2003) pp. 317-339.

doi: https ://doi.org/10.1080/0965431032000070811 
[17] A. Church, M. Frost, K. Sullivan, Transport and social exclusion in London, Transport Policy 7 (2000) pp. 195-205.

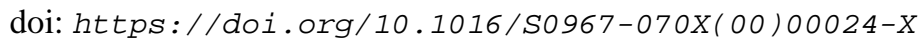

[18] N. Thomopoulos, S. Grant-Muller, M.R. Tight, Incorporating equity considerations in transport infrastructure evaluation: Current practice and a proposed methodology, Evaluation and Program Planning 32 (1998) pp. 351-359.

doi: https ://doi.org/10.1016/j.evalprogplan.2009.06.013

[19] L. Biggiero, F. Pagliara et al., Spatial equity and high-speed rail systems, International Journal on Transport Development and Integration 1 (2) (2017) pp. 194-202.

doi: https ://doi .org/10.2495/TDI-V1-N2-194-202

[20] J. Buhangin, Spatial equity: A parameter for sustainable development in indigenous regions, In: S.S. Zubir, C.A. Brebbia (Eds.), Sustainable City VIII, WIT Press, Southampton, 2013, pp. 1343-1350. doi: https://doi.org/10.2495/SC131142

[21] A. Audikana, Is planning still political? The politicization of high-speed rail in Spain (1986-2016), Political Geography 84 (2021) 102269. doi: https ://doi .org/10.1016/j . polgeo.2020.102269

[22] L. Wang, X. Duan, High-speed rail network development and winner and loser cities in megaregions: The case study of Yangtze River delta, China, Cities 83 (2018) pp. 71-82.

doi: https ://doi.org/10.1016/j.cities . 2018.06.010

[23] H. Gulnar, Financing high-speed train investment by revenue sharing certificates (2016) [cited 2021-04-24].

URL https://sbb.gov. tr/wpcontent/uploads/2018/11/HalilG\%c3\%bclnar.pdf

[24] F. Akin, F. Sultanoglu, 150th year of railways from 1856 to 2006 (1856'dan 2006'ya demiryollarinin 150 yili). 1st Edition, Gurup Matbaacılık A.S., Ankara, 2006 (in Turkish).

[25] Rail Turkey. Urban rail systems (2021) [cited 2021-04-24]. URL https://railturkey.org/travel/trains/hst 
[26] Ministry of Environment and Urbanisation of Republic of Turkey, Environmental indicator, Highway-railway network intensity (2021) [cited 2021-04-24].

URL https://cevreselgostergeler.csb.gov.tr/en/highway- - railway-network-intensity-i-86034

[27] TCDD Tasimacilik A.S. Genel Mudurlugu, Annual report 2019 (2019 faaliyet raporu) (2020) (in Turkish) [cited 2021-04-24].

URL

https://WWw.tcddtasimacilik.gov.tr/uploads/images/Stratej i/TCDD-Tasimacilik-2019-Faaliyet-Raporu.pdf

[28] Official Gazette of Republic of Turkey, Regulation on the rights of passengers traveling by rail (T.C. Resmi Gazete, Demiryolu ile seyahat eden yolcularin haklarina dair yonetmelik) (8 March 2019) (in Turkish) [cited 2021-04-24].

URL https://WWw. resmigazete.gov. tr/eskiler/2019/03/201903086. htm

[29] Rail Turkey. High speed trains (2021) [cited 2021-04-24]. URL https://railturkey.org/travel/trains/hst

[30] M.F. Altan, M.C. Kiziltas, A review on the context of comparison of passenger and freight transport and high speed railways, Dicle University Journal of Engineering 11 (1) (2020) pp. 319-328.

[31] Ministry of Industry and Technology of Republic of Turkey General Directorate of Development Agencies. A Socio-economic development ranking research of provinces and regions SEGE-2017, Ministry of Industry and Technology of Republic of Turkey General Directorate of Development Agencies, Ankara, 2017.

[32] Physical map of Turkey (2021) [cited 2021-04-24].

URL https://tr. pinterest . com/pin/742038476076089349

[33] M. Inan, M. Demir, Rail transportation and effects of high speed railway investments in Turkey: Eskisehir - Konya example, Firat University Journal of International Social Sciences 27 (1) (2017) pp. 99-120.

doi: https ://doi.org/10.18069/firatsbed. 346415 
[34] H. Luo, S, Zhao, Impacts of high-speed rail on the inequality of intercity accessibility: A case study of Liaoning Province, China, Journal of Transport Geography 90 (2021) pp. 1-16.

doi: https ://doi.org/10.1016/j . jtrangeo.2020.102920

[35] Milliyet, The map of airports in Turkey: Which provinces have airports? The cities with airports in Turkey (Türkiye havalimanları haritası: Hangi illerde havaalanı vardır? Türkiye'de havalimanı olan sehirler), 4 November 2020 (in Turkish) [cited 2021-04-24].

URL https://WWW. milliyet.com.tr/egitim/haritalar/turkiyehavalimanlari-haritasi-hangi-illerde-havaalani-vardirturkiyede-havalimani-olan-sehirler-6311212

[36] J. Wang, J. Huang, Y. Jing, Competition between high-speed trains and air travel in China: From a spatial to spatiotemporal perspective, Transportation Research Part A 133 (2020) pp. 62-78.

doi: https://doi.org/10.1016/j.tra.2019.12.030

[37] X. Ren, Z. Chen et al. Impact of high-speed rail on social equity in China: Evidence from a mode choice survey, Transportation Research Part A 138 (2020) pp. 422-441.

doi: https://doi.org/10.1016/j.tra.2020.05.018

[38] F. Pagliara, F. Mauriello, Y. Ping, Analyzing the impact of high-speed rail on tourism with parametric and non-parametric methods: The case study of China. Sustainability 13 (2021) pp. 1-10.

doi: https://doi .org/10.3390/su13063416

[39] M. Afsar, Z. Erdogan et al. A Study of the effects of high speed train on Eskisehir (Yuksek hizli trenin Eskisehir'e etkileri arastirmasi). Eskisehir Ticaret Odasi Yayinlari, Eskisehir, (2015) (in Turkish).

[40] P. Coppola, F.D. Fabiis, Impacts of interpersonal distancing on-board trains during the COVID-19 emergency, European Transport Research Review 13 (13) (2021) pp. 1-12.

doi: https ://doi.org/10.1186/s12544-021-00474-6 